\title{
Preliminary results on induction of triploidy in salmonids using heat shocks
}

\author{
I. HOLMEFJORD *, T. REFSTIE * and J. HøSTMARK ** \\ * Department of Animal Genetics and Breeding, Agricultural University of Norway, \\ $1432 \stackrel{\AA}{A}-\mathrm{NLH}$, Norway \\ ** The Gade Institute, Department of Pathology, University of Bergen, \\ S016 Haukeland Hospital, Norway
}

Triploidy has been induced in Atlantic salmon (Salmo salar) using heat shocks shortly after insemination. The same heat shocks also produced triploid hybrids between Atlantic salmon and Sea trout (Salmo trutta) and between Atlantic salmon and Arctic char (Salvelinus alpinus). Heat shock at 32 "C and $34^{\circ} \mathrm{C}$ given for 4 and 2 minutes, respectively, gave high frequensis of triploid frys. To state the ploidy DNA-content in embryo cells were measured using flowcytometric DNA-analysis.

When using irradiated sperm diploid gynogenetic Atlantic salmon fry has been produced by a wide range of heat shocks. This suggest that triploidy also could be induced by the same wide range of heat shocks.

\section{Colour variability of hair coat in successive unselected generation of standard mink}

\author{
J. MACIEJOWSKI and G. JEZESKA
}

Agricultural Academy, 20-934 Lublin, ul.Akademicka 13, Poland

In the herd of standard minks characterized by a sufficient level of economic traits selection for the colour of hair coating was stopped in the experimental group. During five years 1976-1980, 5 generations were obtained. The offspring of unselected animals were evaluated each year at the period of full fur maturity and a considerably lower level of the trait was noticed in comparison with the selected group. In the last year of the experiment, due to food insufficiency the trait level in both groups decreased significantly and reach the same level.

\section{Repeatability of exterior traits estimations in different species of fur animals}

\author{
G. JEZESKA and J. MACIEJOWSKI
}

Agricultural Academy, 20-934 Lublin, ul.Akademicka 13, Poland

A test was carried out for the repeatability of marks given to the fur animals of three species fox (silver), polar fox (blue) and mink (standard). The tested persons marked three the same animals which were presented in the succession unknown to them. The repeatability of marks was evaluated for the group and individually for each tested person. Minks appeared to be the most difficult to mark and fluctuation of repeatability $\left(r^{\prime}\right)$ were from 0.309 to 0.731 . Silver foxes were the easiest to mark from 0.861 to 1.00 . The test showed a considerable individual differentiation of the tested person's qualifications which could affect the selection efficiency if all of them received a licence to mark furbearing animals. 